\title{
Recenze na text Niektoré z úskalí evolučnej ontológie
}

\author{
Zdenka Sokolíčková \\ Envigogika 8 (3) - Recenze
}

Text P. Saba a L. Sabové dobře vystihuje slabiny $v$ mnohém inspirativní koncepce Josefa Šmajse, kterou tento filosof vypracoval a následně bohužel jen minimálně rozvíjel v návaznosti na její věcnou kritiku. Ztotožňuji se s názorem autorů, že Šmajsova evoluční ontologie vychází z oprávněného znepokojení, avšak její ústřední teze, totiž bytostná protiprírodnost kultury, je exces. Zaprvé, jak ostatně ukázala kulturní antropologie a další vědy o kultuře, kultura se z přírody vyvinula a stále vyvijí, nestojí tedy radikálně (neboli od základu, od kořene) proti ní. Existují jistě takové projevy kultury, které přírodě škodí (např. neoliberalistická iluze o možnosti zpeněžit cokoliv, i vzduch nebo čistou vodu), ale existují i takové, které jsou $k$ ní ve vztahu neutrálním (např. $v$ textu zmiňované projevy uměleckého ducha) či dokonce pozitivním (např. myšlenka ochrany prírody).

Autoři přehledně prezentují čtyři body, o které opírají svou kritiku. Výhrady, respektive otázky mám $\mathrm{k}$ třetímu $\mathrm{z}$ nich, totiž ke zkušenosti a selskému rozumu při rozlišování kultury a antikultury. Proč zavádět nový pojem antikultury? Vznikal by tak třetí systém, vedle toho prírodního a kulturního bychom tu měli systém antikulturní, jehož hranice by měl určovat selský rozum (kterým se např. v právních sporech těžko argumentuje). Kultura je termín nehodnotící a jak už bylo řečeno, její součástí jsou i takové ideje, normy a artefakty, které člověku nebo přírodě neprospívají. Zvláštní vymezení tzv. antikultury se mi pro debatu nezdá př́nosné.

Vítám obranu antropocentrismu; ukázkou radikálního odmítnutí antropocentrismu je

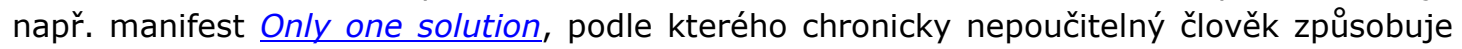
sám sobě, mimolidským zvířatům a prírodnímu světu obecně tolik utrpení, že jediným řešením je zánik lidského druhu. Takový postoj je postaven na beznaději a touze zbavit se odpovědnosti jednou provždy, zatímco soudobý svět, a na tom bych se předpokládám s autory také shodla, potřebuje více než cokoliv jiného právě naději a odpovědnost.

Doporučuji text k publikování, nebot' se domnívám, že může přispět k plodnému rozvinutí diskuse. Je škoda, že se environmentalisté tak často rozcházejí na poli teorie (viz otázka Je, nebo není kultura protiprírodní?), místo aby utvořili napříč teoretickými tábory jednotné hnutí s konkrétními politickými dopady.

V Praze, 9. srpna 2013

Mgr. Zdenka Sokolíčková, Ph.D. M.A.

Pracuje na Katedře kulturních a náboženských studií Univerzity Hradec Králové, e-mail: zdenka.sokolka@gmail.com

Je mj. autorkou knihy Sokolíčková, Zdenka. Člověk v pokorném závazku vưči světu: studie z ekologické etiky. Červený Kostelec : Pavel Mervart, 2012. 